\title{
HIGH-TECHNOLOGY INDUSTRIES COMPETITIVENESS AND REGIONAL ALLOCATION BY NUTS 3 REGIONS IN LATVIA
}

\author{
Astra Auzina-Emsina, Velga Ozolina \\ Riga Technical University, Latvia \\ astra.auzina-emsina@rtu.lv; velga.ozolina@rtu.lv
}

\begin{abstract}
Competitiveness is the key factor in order to reach the economic transformation, smart growth, governance and legal framework for the state and society for sustainable development that are stated as the major goals in the current planning period in Latvia. High-technology industries are the main drivers of economic activity in developed economies. To ensure data comparability, the official definition of the high-technology industries by Eurostat is applied in this research including two industries: manufacture of basic pharmaceutical products and pharmaceutical preparations and manufacture of computer, electronic and optical products. The research aims to analyse high-technology industries in Latvia taking into account the competitiveness and the regional allocation using a set of several indicators. According to NUTS 3, Latvia is subdivided into 6 regions; however, the high-technology industries are regionally allocated mainly in two regions, Riga and Pieriga regions. Manufacture of basic pharmaceutical products etc. employs $99 \%$ of employees in these two regions, manufacture of computer etc. products $-81 \%$ despite the fact that only $54 \%$ of employees reside in these two regions. The research confirms that the high-technology regional allocation depends on available labour resources and also education and professional training facilities in the region. We conclude that the high-technology industries are competitive in the global market as the share of the high-tech products in total exports is several times higher than the share of these industries in the manufacturing sector or in total economy. The global competitiveness of Latvia's high-tech industries is stable and gradually rising.
\end{abstract}

Key words: high-technology industries, competitiveness, regional allocation, NUTS 3 regions.

\section{Introduction}

High-technology industries are anticipated as the main economic development drivers of developed economies. Researchers (Brown, Martinsson, \& Petersen, 2015) argue that the countries with larger high-tech sectors exhibit faster future rates of economic growth. However, numerous problems are observable regarding both theoretical and practical application issues related to the high-technology industries.

High-technology industries are slightly differently defined by various authors and institutions; however, in order to maintain data comparability and ensure data availability, the official definition of Eurostat is applied in this research. According to the Eurostat (Eurostat, 2016a), high-tech classification of manufacturing industries based on NACE Rev.2 2-digit level hightechnology industries are the following: manufacture of basic pharmaceutical products and pharmaceutical preparations (NACE Rev.2 2-digit level code: C21) and manufacture of computer, electronic and optical products (C26). If more detailed (or disaggregated) data are available and NACE Rev.2 3-digit level is applied, then in addition, manufacture of air and spacecraft and related machinery (C30.3) is also included into high-technology industries.

Some authors define the high-technology industries even more precisely. For example, (Kenney \& Patton, 2005) defined these three high-technology industries: semiconductors, telecommunications equipment, and biotechnology researching the entrepreneurial support network for start-up companies in high-technology industries in the USA. However, analysis in such a detail is not possible in Latvia due to the lack of the data.

The research aims to analyse the high-technology industries in Latvia taking into account the competitiveness and the regional allocation. The aim is achieved by:

1. Analysing the theoretical and practical background;

2. Defining the indicators and the data sources, as well as by examining the data availability and comparability;

3. Performing the analysis and comparison of the selected indicators;

4. Elaborating conclusions and recommendations in order to improve the high-technology industries competitiveness taking into account the regional allocation.

The research focuses on the current situation and latest trends, hence the appropriate research period is selected. It should be stressed that regarding competitiveness it is significant to analyse dynamics and tendencies rather than focus on figures in a certain time period (for example, in a certain year) if it is possible.

High-technology companies in regions demand a variety of high-skilled professionals and engineers as in any major high-tech city. Hence the availability and quality of the labour resources available in the region where the company operates is very important and should be analysed as well.

The results of the research on the regional knowledge production as a determinant of the hightechnology entrepreneurship in Germany (Huelsbeck 
\& Pickave, 2014) clearly show that the hightechnology entrepreneurship is highly dependent on regional knowledge production by industry and university, while technology entrepreneurship does not largely depend on these factors. Moreover, research in the South European countries (Fernández López, Pérez Astray, Rodeiro Pazos, \& Calvo, 2015) indicate that more innovative enterprises (which include also high-technology enterprises) are more interested in collaborating with the universities. Other author (Castro, 2015) stresses that knowledge and technological innovation are the key sources to sustain competitive advantage and survive in the hightechnology industries and that external relationships and networks are necessary to develop better and faster innovations.

Some authors have examined the contribution of regional universities for regional development in Latvia and they emphasize that GDP per capita in cities with regional universities is higher than in other cities in Latvia (Sloka \& Vilcina, 2009). However, the findings argue that the regional knowledge and training have significant impact on the regional development and regional allocation of the hightechnology companies.

The evidence of the authors examining the wages in high-tech companies in high-tech cities and in other cities in the USA (Echeverri-Carroll \& Ayala, 2009) argues that employees earn raw wages that are on average $17 \%$ higher than the wages of the employees in other cities, and it is a result of the high-tech cities actually making employees more productive. These findings stress the need and importance of selfassessment and self-declaration of cities and also regions (whether to attract high-tech companies and create appropriate business environment) and constant high-tech policy.

In scientific literature, relatively many authors have examined the regional development and regional differences in Latvia (including NUTS 3 regions) by various aspects, as the EU funds allocation by regions (Latviete, 2010), endogenous factors in regional development (Abeltina, Zvirgzdina, \& Ozols, 2016), regional policy and readiness for structural change (Šipilova, 2014), the role of universities (including regional universities) in lifelong learning process (Jurgelane, Grizane, \& Jankova, 2016) etc. The above-mentioned authors and researchers represent a wide variety of institutions, and it emphasizes that regional aspects are important to wide scientific and professional audience. However, there are no notable studies devoted to the high-technology industries and their regional allocation in Latvia. Hence this research is topical and needed for economists and scientists, government, policy makers, business and non-government institutions and associations etc.

\section{Materials and Methods}

The data sources for the statistical data used in the research are the Central Statistical Bureau of Latvia and Eurostat. The use of the indicators from the Eurostat data ensures a unified methodology for all selected countries and thus the data comparability (comparability across countries and time periods).

The research is focused on Latvia. In addition, the average values of the EU countries' indicators and data on several EU countries are used for comparisons and analysis. In this research, the EU is a union of 28 member states.

But some authors use other type of data and data sources. The authors (Huelsbeck \& Pickave, 2014) in the research used hand-collected data from multiple sources; however, this method is not applicable for Latvia due to the data incomparability in multiple sources (data collected by institutions, associations, non-government institutions etc.) as in most cases there are statistical methodological problems and inconsistencies.

The NUTS classification used in the research is Nomenclature of territorial units for statistics applied by Eurostat (Eurostat, 2017) that is a hierarchical system for dividing up the economic territory of the EU for the purpose of:

1. Collection, development and harmonisation of European regional statistics

2. Socio-economic analyses of the regions

- NUTS 1: major socio-economic regions

- NUTS 2: basic regions for the application of regional policies

- NUTS 3: small regions for specific diagnoses

3. Framing of EU regional policies.

- Regions eligible for support from cohesion policy have been defined at NUTS 2 level.

- By far the Cohesion report has generally been made at NUTS 2 level.

The NUTS classification has regular amendments adopted by Commission Regulation. The fourth, extraordinary amendment to the annexes was adopted by Commission Regulation (EU) No 868/2014. It entered into force on 8 August 2014 and had to be applied in Eurostat from 1 January 2016. The Fifth Amendment to the annexes was a regular one adopted by Commission Regulation (EU) 2016/2066. It entered into force on 19 December 2016 and will be applied in Eurostat from 1 January 2018 (Eurostat, 2017).

The current NUTS classification lists 98 regions at NUTS 1, 276 regions at NUTS 2 and 1342 regions at NUTS 3 level (Eurostat, 2017). Latvia is split into 1 region (Latvia) at NUTS 1, 1 region at NUTS 2 and 6 regions (Kurzeme (NUTS code: LV003), Latgale (LV005), Riga (LV006), Pieriga (LV007), Vidzeme (LV008), Zemgale (LV009)) at NUTS 3 level. 
As the research focuses on the regional aspects of the high-technology industries in Latvia, NUTS 3 level is applied in the research.

Both quantitative and qualitative data analysis methods and analytic method have been used in the research. Several indicators for evaluation of the dynamics of the high-technology industries have been selected and are used in the research.

The following indicators have been selected:

1. Exports of high technology products as a share of total exports - Eurostat (Eurostat, 2016c) is selected as the appropriate data source;

2. Values added by regions in Latvia - data source is Eurostat (Eurostat, 2016b);

3. Economically active population and the number of employed persons by regions - data source is CSB (Centrālā Statistiskas pārvalde, 2017b)

4. High-tech industries value added by regions - data source is CSB (Centrālā Statistikas pārvalde, 2016);

5. High-tech employment (number of employed persons) by regions - data source is CSB (Centrālā Statistikas pārvalde, 2016);

6. Gross average monthly wages and salaries in high-technology industries - data source is CSB (Centrālā Statistikas pārvalde, 2017a).

The research covers the time period from 2004 to 2015. It can be divided into three periods - 20042008 (pre-crisis), 2008-2010 (crisis) and starting from 2011 (post-crisis) according to (Auzina-Emsina, 2014) in order to analyse the trends and correlations. For some indicators data were available for shorter time period. These data have been used in the research anyway as the research aims to include the maximum available data. It is specified in the text if the time series of the indicators are not available for the whole period.

\section{Results and Discussion}

General regional development trends in Latvia

In the EU, Eurostat has been gathering and publishing the data on trade and exports of the high technology products as a share of total exports since 2007. The data is published in section 'statistics on high-tech industry and knowledge-intensive services' that is sometimes referred to as simply 'high-tech statistics' (Eurostat, 2016d). The data cover all member states of the EU as well as candidate countries and European Free Trade Association (EFTA) countries.

In 2015, exports of the high-technology products as a share of total exports accounts for $9.8 \%$ in Latvia. This share has doubled in recent years form $4.6 \%$ in 2007 to $9.8 \%$ in 2015 (see Figure 1).

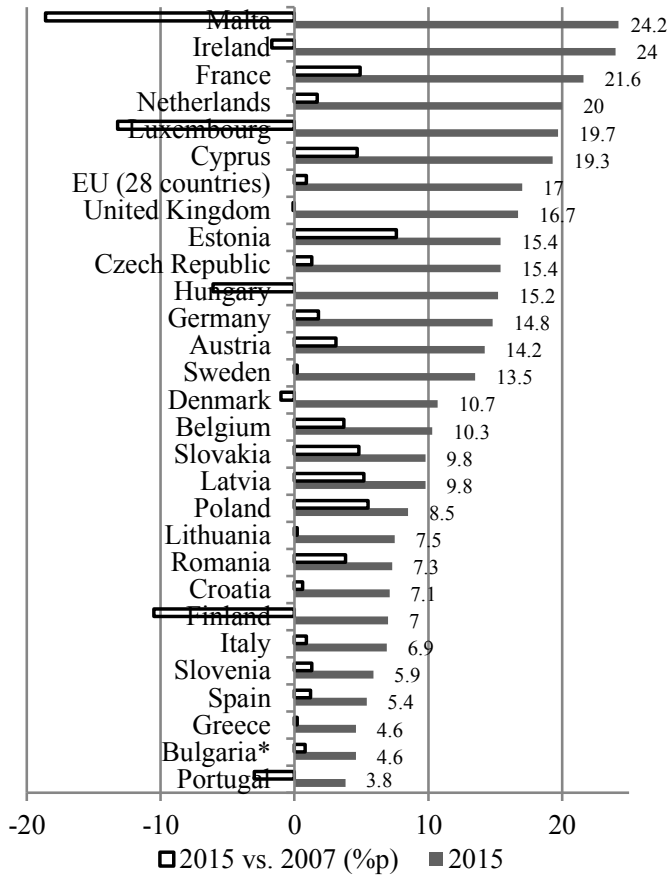

Figure 1. Exports of high-technology products as a share of total exports in $2015(\%)$ and change since 2007 (\%p).

Economic activity is allocated unequally in country's territory. It is a common observation and it is not an abnormal situation in Latvia or neighbouring countries and countries in the region (as Estonia, Lithuania, Russia, Belarus, Sweden, Poland, Finland etc.). This is observable in both small and large countries by territory, also in both economically highly developed and developing countries etc.

Regional statistics takes time to be gathered, processed and published by the statistical offices hence a significant time delay is observed. According to the latest published data regarding the economic activity by regions (NUTS 3), in 2013, Riga region is the outstanding leader as it accounted for $53 \%$ of the gross value added, Pieriga region accounted for $15 \%$, Kurzeme $-10 \%$, Latgale $-8 \%$, Zemgale $-8 \%$, and Vidzeme $-6 \%$.

Economic activity in Riga region correlates with the general economic well-being and economic trends in export market, hence Riga region had slightly lost the share in the final years compared to the fast economic development period (in 2006-2007; Riga region accounted for $56 \%$ of the gross value added in Latvia) and also during the economic crisis period (2008 - 2010). The lowest point was in $2011(51 \%)$. When the export markets and also the domestic economy started to recover, it resulted in faster economic development in Riga region in comparison with the rest of Latvia (see Figure 2). 


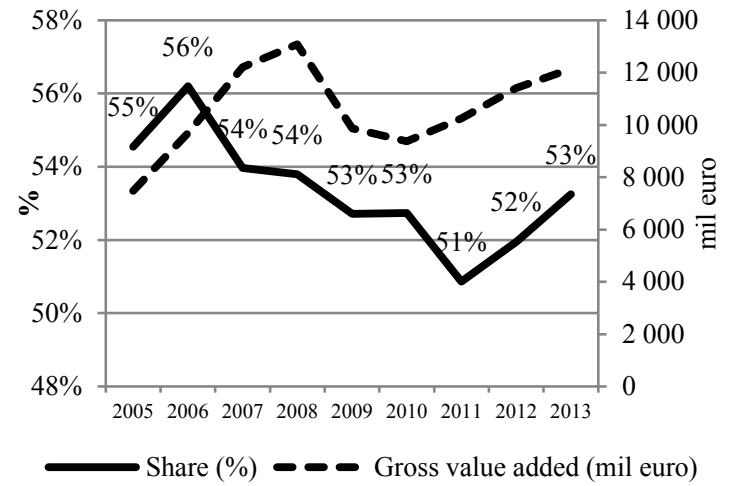

Figure 2. Gross value added at basic prices in Riga region and its share in 2005 - 2013 (mil euro; \%).

As all the other regions have significantly smaller share in the economy, these regions are illustrated separately (see Figure 3). Pieriga region is the second largest region by gross value added produced, however, it significantly lags behind the leading region (Riga region) with the share of $15 \%$ in 2013. A specific characteristic regarding Pieriga region is that it has gradually increased its share in economy despite the economic fluctuations (fast economic growth, crisis, recovery) - from $12 \%$ in 2005 to $15 \%$ in 2013 . The rest of the regions have a stable share in the economy, and the fluctuation interval of their shares mainly does not exceed one percentage point. Thus, stable and notable trends are not observable.

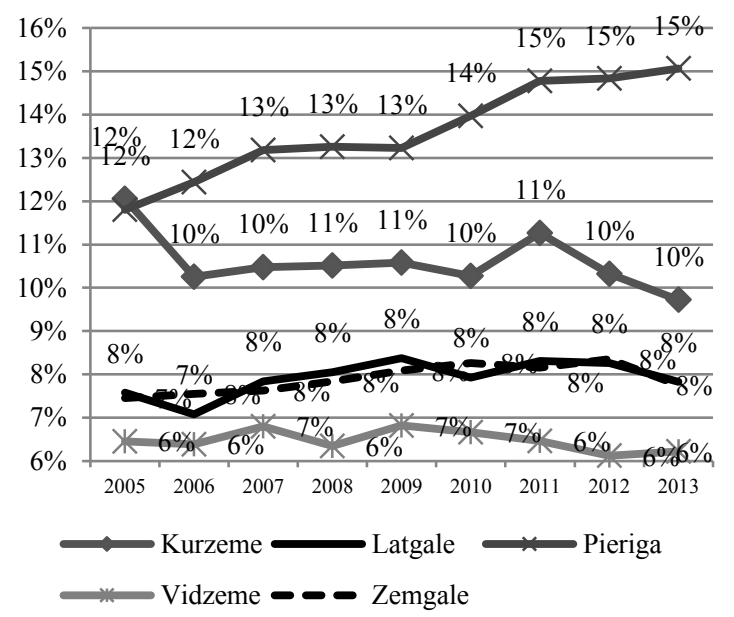

Figure 3. Share of gross value added at basic prices in Pieriga region, Kurzeme, Latgale, Zemgale, Vidzeme in 2005 - 2013 (\%).

The number of the economically active population shows the amount of potentially available labour force, but the number of employed persons shows the amount of actually available and used labour force in the region. The structure of the economically active population and employed persons by regions are considerably different from the structure of the gross value added. Riga regions holds its leading position but the share is notably lower $-34 \%$ of the economic active population and $35 \%$ of the total number of employed persons lived in Riga region in 2015 and accordingly 34\% and 34\% in 2013 (for data comparability with the value added data) (see Figure 4).

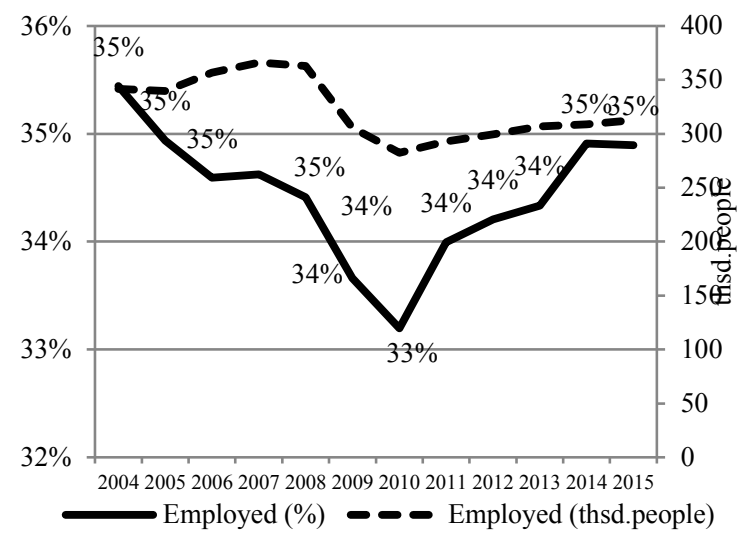

Figure 4. Employed persons in Riga region in $2004-2015$ (\%; thsd. people).

According to the methodology of CSB, the territorial breakdown is obtained by the place of the residence of the respondent, so economically active persons actually live in particular regions, but the employees can be employed is any region.

In the period analysed, the share of employed persons with a place of residence in Pieriga region has gradually increased from $17 \%$ in 2004 to $20 \%$ in 2015 (see Figure 5).

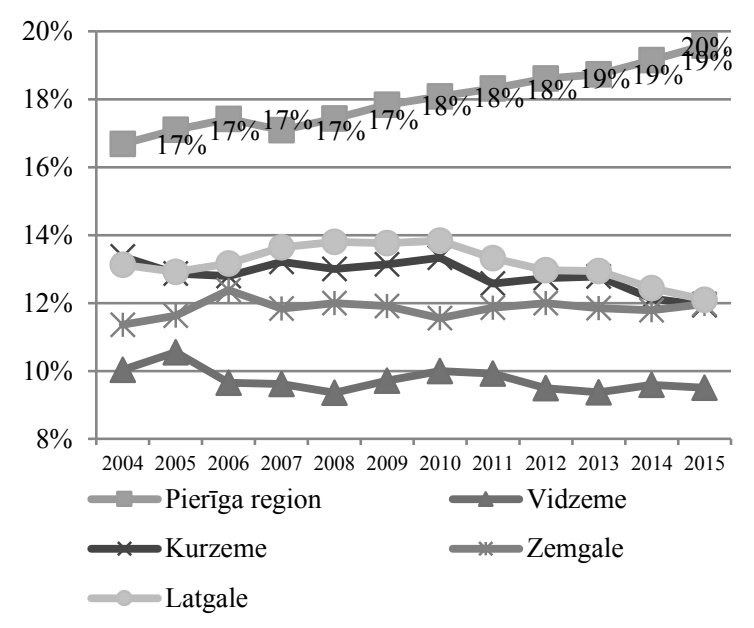

Figure 5. Number of employed persons in Pieriga region, Kurzeme, Latgale, Zemgale, Vidzeme in $2004-2015(\%)$. 
The rest of the regions have stable positions and only some changes within 2 percentage points can be detected.

Regional development of the high-technology industries in Latvia

The latest data on the high-tech industries by regions in Latvia (by CSB) of 2014 have significant limitation due to the obligations to ensure the confidentiality of data. In practice, if one or only some companies are in a certain industry, the data are not published, but included in total number and overall computations. According to CSB data, in 2014 the high-technology industries created the gross value added 151 mil euro or $0.7 \%$ of the total gross value added or $5.8 \%$ of value added in manufacturing sector. The dynamics of the share of the high-technology industries in total gross value added are presented in Figure 6.

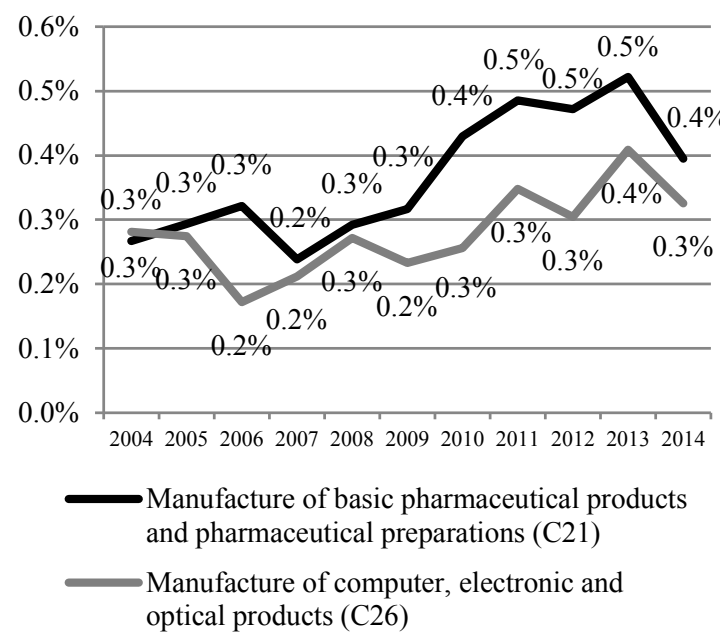

Figure 6. Share of High-technology industries in total gross value added in $2004-2014$ (\%).

Due to the data confidentiality obligations, data on the value added of the manufacture of basic pharmaceutical products and pharmaceutical preparations $(\mathrm{C} 21)$ by regions are published only regarding Zemgale; but - Manufacture of computer, electronic and optical products (C26) by regions are published on Riga region, Kurzeme and Zemgale.

Employment data contain more information and give solid background for conclusions and recommendations for the government policy.

The analysis of persons employed shows that the place of residence of the employed persons in manufacture of basic pharmaceutical products and pharmaceutical preparations (C21) are dominantly only in two regions - Pieriga region (56\%) and Riga region $(43 \%)$ (see Table 1$)$. There are two leading companies in the industry in Latvia - AS 'Grindeks' (that is located in Riga) and AS 'Olainfarm' (located in Olaine that is in Pieriga region). Only one per cent of persons employed in this high-technology industry have a place of residence in other regions. In total, the industry employs $0.2 \%$ of all persons employed in 2014.

Table 1

\section{Employment of manufacture of basic pharmaceutical products and pharmaceutical preparations in Latvia in 2014}

\begin{tabular}{|l|c|c|}
\hline \multirow{2}{*}{ Region } & \multicolumn{2}{c|}{$\begin{array}{c}\text { Manufacture of basic pharmaceutical } \\
\text { products and pharmaceutical } \\
\text { preparations (C21) }\end{array}$} \\
\cline { 2 - 3 } & Persons & Structure \\
\hline Riga region & 810 & $43 \%$ \\
\hline Pieriga region & 1045 & $56 \%$ \\
\hline Vidzeme & 2 & $0 \%$ \\
\hline Kurzeme & $\mathrm{x}$ & $\mathrm{x}$ \\
\hline Zemgale & 6 & $0 \%$ \\
\hline Latgale & $\mathrm{x}$ & $\mathrm{x}$ \\
\hline TOTAL & $\mathbf{1 8 6 3}$ & $\mathbf{1 0 0 \%}$ \\
\hline
\end{tabular}

$\mathrm{x}$ - no data

The analysis of persons employed in the manufacture of computer, electronic and optical products (C26) by region shows that Riga region is the absolute leader with $65 \%$ of persons employed in the industry in 2014 (see Table 2). Pieriga region is the next most significant region where employed persons live $-16 \%$. Both regions - Riga and Pieriga regions together have dominant position as they account for $81 \%$. In total, the industry employs $0.2 \%$ of all persons employed in 2014.

Table 2

Employment of Manufacture of computer, electronic and optical products in Latvia in 2014

\begin{tabular}{|l|c|c|}
\hline \multirow{2}{*}{\multicolumn{1}{|c|}{ Region }} & \multicolumn{2}{c|}{$\begin{array}{r}\text { Manufacture of computer, electronic } \\
\text { and optical products (C26) }\end{array}$} \\
\cline { 2 - 3 } & Persons & Structure \\
\hline Riga region & 963 & $65 \%$ \\
\hline Pieriga region & 239 & $16 \%$ \\
\hline Vidzeme & 25 & $2 \%$ \\
\hline Kurzeme & 152 & $10 \%$ \\
\hline Zemgale & 15 & $1 \%$ \\
\hline Latgale & 81 & $5 \%$ \\
\hline TOTAL & $\mathbf{1 4 7 5}$ & $\mathbf{1 0 0 \%}$ \\
\hline
\end{tabular}


Gross average monthly wages and salaries in high-technology industries in $\mathbf{2 0 1 5}$ (in euro)

\begin{tabular}{|c|c|c|c|c|c|}
\hline & $\begin{array}{c}\text { Total } \\
\text { economy } \\
\text { (average) }\end{array}$ & $\begin{array}{l}\text { Manufacture of basic } \\
\text { pharmaceutical products } \\
\text { and pharmaceutical } \\
\text { preparations }\end{array}$ & $\begin{array}{l}\text { Above the } \\
\text { average } \\
(\%)\end{array}$ & $\begin{array}{l}\text { Manufacture } \\
\text { of computer, } \\
\text { electronic and } \\
\text { optical products }\end{array}$ & $\begin{array}{c}\text { Above the } \\
\text { average } \\
(\%)\end{array}$ \\
\hline Total in the industry & 818 & 1181 & $44 \%$ & 1079 & $32 \%$ \\
\hline $\begin{array}{l}\text { total, excluding private } \\
\text { sector enterprises with } \\
\text { number of employees }<50\end{array}$ & 883 & 1194 & $35 \%$ & 1214 & $37 \%$ \\
\hline Public sector & 853 & $\mathrm{x}$ & $\mathrm{x}$ & $\mathrm{x}$ & $\mathrm{x}$ \\
\hline Private sector & 799 & 1181 & $48 \%$ & 1079 & $35 \%$ \\
\hline $\begin{array}{l}\text { private enterprises with } \\
\text { number of employees }>=50\end{array}$ & 916 & 1194 & $30 \%$ & 1214 & $33 \%$ \\
\hline
\end{tabular}

$\mathrm{x}$ - no data in the source (magnitude zero).

The analysis of the value added by industry and persons employed by industry shows that the high-technology industries in Latvia are economic drivers - with fewer resources they produce larger value added than on average in the economy. Manufacture of basic pharmaceutical products and pharmaceutical preparations employs only $0.2 \%$ but creates $0.5 \%$ of the value added.

Similar results are obtained regarding the manufacture of computer, electronic and optical products - the industry employs $0.2 \%$ of persons employed in the economy, but it creates $0.3 \%$ of the value added.

The analysis of the wages and salaries in the hightechnology industries and the comparison with the average level in the economy shows that wages are significantly higher in the high-technology industries than on average in the economy. The average gross monthly salary in manufacture of basic pharmaceutical products and pharmaceutical preparations was by 44\% higher in 2015 (see Table 3), but in Manufacture of computer, electronic and optical products - by $32 \%$ higher.

Definitely, high-technology industries demand employees with specific education, training, knowledge and skills. And in most cases for new employees that moved or shifted from other industries (even medium-high technology industries as manufacture of chemicals and chemical products (C20), manufacture of electrical equipment (C27) etc. that are alike to some extent to high-technology industries) at least additional training at companies (at company level) is needed.

Regional professional and higher education institutions can be helpful in this process to ensure both companies needs for qualified employees and potential employees with the necessary skills and training.
It means that any local government should take into account that the high-technology industry companies (production plants) have high labour productivity and pay higher wages to employees that leads to the higher personal income tax payments in local budgets etc. High productivity is one of the key factors that ensures and maintains industry's competitiveness in the national and global market.

Currently, the competitiveness issues are taken seriously by the economic policy makers including technology improvement and upgrade programs, supporting innovation activity, high-tech start-up companies etc. supported or partly financed by the government and the EU funds.

\section{Conclusions}

We conclude that high-technology industries are competitive in the global market as the share of high-tech products exports of total exports are several times higher than the share of these industries in manufacturing sector or in total economy. The global competitiveness of Latvia's high-tech industries is stable and gradually rising. Also, the high-technology companies offer significantly higher wages and salaries that forms relative advantage over other industries in Latvia.

We conclude that regional allocation of hightechnology industries in Latvia is stable and notable changes or shifts are not observable or even foreseeable in the nearest future. The research confirms that the high-technology regional location depends on available labour resources and also education and professional training facilities in the region.

Recommendations for government and policy makers: 1) Any local government should take into account that the high-technology industry companies have high labour productivity and pay higher wages to employees that leads to the higher 
personal income tax payments in local budgets etc.; 2) policy makers should be aware of the fact that high-technology companies demand employees with specific education, training, knowledge and skills. And in most cases for new employees that shifted from even alike industries at least additional training is needed; 3) Competitiveness of hightechnology industries is sensitive to legislation changes (especially regarding employment and taxation), hence the changes should be predictable.
Unexpected changes may hinder the development of these industries.

\section{Acknowledgements}

The paper was supported by the National Research Program 5.2. 'Economic Transformation, Smart Growth, Governance and Legal Framework for the State and Society for Sustainable Development a New Approach to the Creation of a Sustainable Learning Community (EKOSOC-LV)'.

\section{References}

1. Abeltina, A., Zvirgzdina, R., \& Ozols, J. (2016). Endogenous factors in Latvian regional development. Problems and Perspectives in Management, 14(3), 21 - 30. DOI: 10.21511/ppm.14(3).2016.02.

2. Auzina-Emsina, A. (2014). Labour productivity, economic growth and global competitiveness in postcrisis period. (E. Gimzauskiene, Ed.) 19th International scientific conference Economics and Management 2014 (ICEM-2014), 156, 317 - 321. DOI: 10.1016/j.sbspro.2014.11.195.

3. Brown, J.R., Martinsson, G., \& Petersen, B.C. (2015). Stock markets, credit markets, and technology-led growth. Journal of Financial Intermediation. DOI: 10.1016/j.jfi.2016.07.002.

4. Castro, G.M.-d. (2015). Knowledge management and innovation in knowledge-based and high-tech industrial markets: The role of openness and absorptive capacity. Industrial Marketing Management, 47, $143-146$.

5. Centrālā Statistikas pārvalde (2016). Uzṇēmumu galvenie uzṇēmējdarbības rādītāji statistiskajos reǵionos (Basic indicators of business activity of merchants (commercial companies) by region). Retrieved November 24, 2016, from: www.csb.gov.lv. (in Latvian).

6. Centrālā Statistikas pārvalde (2017a). Average monthly wages and salaries by kind of activity. Retrieved February 6, 2017, from: http://www.csb.gov.lv/en/dati/statistics-database-30501.html.

7. Centrālā Statistiskas pārvalde (2017b). Population by labour status and statistical region. Retrieved February 6, 2017, from: data.csb.gov.lv/pxweb/en/Sociala/Sociala_ikgad_nodarb/?tablelist=true\&rxid $=$ a79839fe-11ba-4ecd-8cc3-4035692c5fc8.

8. Echeverri-Carroll, E., \& Ayala, S. (2009). Wage differentials and the spatial concentration of high-technology industries. Papers in Regional science, 88(3), 623 - 641. DOI: 10.1111/j.1435-5957.2008.00199.x.

9. Eurostat (2016a). Glossary:High-tech classification of manufacturing industries. Retrieved November 4, 2016, from: http://ec.europa.eu/eurostat/statistics-explained/index.php/Glossary:High-tech_classification_ of_manufacturing_industries.

10. Eurostat (2016b). Gross domestic product (GDP) at current market prices by NUTS 3 regions. Retrieved January 16, 2017, from: http://ec.europa.eu/eurostat/data/database.

11. Eurostat (2016c). High-tech exports. Retrieved November 24, 2016, from: http://ec.europa.eu/eurostat/ web/products-datasets/-/tin00140.

12. Eurostat (2016d). High-tech industry and knowledge-intensive services. Retrieved February 6, 2017, from: http://ec.europa.eu/eurostat/cache/metadata/en/htec_esms.htm.

13. Eurostat (2017). NUTS - Nomenclature of territorial units for statistics. Retrieved January 17, 2017, from: http://ec.europa.eu/eurostat/web/nuts/overview.

14. Fernández López, S., Pérez Astray, B., Rodeiro Pazos, D., \& Calvo, N. (2015). Are firms interested in collaborating with universities? An open-innovation perspective in countries of the South West European Space. Service Business, 9(4). DOI: 10.1007/s11628.

15. Huelsbeck, M., \& Pickave, E.N. (2014). Regional knowledge production as determinant of high-technology entrepreneurship: empirical evidence for Germany. International entrepreneurship and management journal, 10(1), 121 - 138. DOI: 10.1007/s11365-011-0217-9.

16. Jurgelane, I., Grizane, T., \& Jankova, L. (2016). Role of university lifelong learning process implementation. In S. Treija, \& S. Skujeniece (Ed.), 22nd Annual International Scientific Conference on Research for Rural Development, 2, pp. 246 - 253. Jelgava.

17. Kenney, M., \& Patton, D. (2005). Entrepreneurial geographies: Support networks in three high-technology industries. Economic geography, 81(2), $201-228$. 
18. Latviete, I. (2010). Assets of the European union funds on the region development in Latvia. 16th Annual International Scientific Conference - Research for Rural Development 2010; Jelgava; Latvia; 19 May 2010 through 21 May 2010, 2, pp. 55 - 62. Jelgava.

19. Sloka, B., \& Vilcina, A. (2009). Contribution of Regional Higher Education Institutions for Regional Development. 10th International Scientific Conference on Economic Science for Rural Development, 19, pp. $58-63$. Jelgava.

20. Šipilova, V. (2014). Regional policy as indicator of readiness for structural change: The case of Latvia. Mediterranean Journal of Social Sciences, 5(13), 391 - 397. DOI: 10.5901/mjss.2014.v5n13p391. 